\title{
Oliver Twist and Inklings of 'Grotesque'
}

\author{
Ehsan Hafezi Kermani \\ Sabz Institute of Higher Education, Iran \\ Roshanak Fazli \\ Sabz Institute of Higher Education, Iran
}

\section{Introduction}

\section{A. Characters}

The characters predominantly concentrated are Oliver himself, the old Jew Fagin and some of the other characters described in their appearances and gestures as caricatures. Oliver Twist, who can be considered as the axis of the novel, is the hero of the novel. He remains intact by Fagin's realm. Fagin and his band stabs to put him in their group but Oliver always wants to escape from this world and situations. There is one more clue about the characters called 'animal imagery'. This imagery purpose is to highlight stressfulness and horrendous atmosphere of the Victorian period. Most of the characters have some features or sometimes they are being told as animals like 'dog'. When Oliver is in the parish workhouse and he defines a boy in there as follows "he had a wild, hungry eyes" $(O T, 12)$ in which here grotesquery argues to the idea of animals versus humans mixed as opposites or a kind of bizarre descriptions.

In chapter eight, Dickens puts his pen professionally to describe one of his unforgettable characters that is Artful Dodger like a caricature.

He was a snub-nosed, flat browed, common faced boy enough, and as dirty a juvenile as one would wish to see. He was short of his age, with rather bowlegs, and little, sharp, ugly eyes. His hat was struck on the top of his head sol lightly, that it threatened to fall off every moment- and would have done so very often, ....He wore a man's coat, which reached nearly to his heels. He had turned the cuffs back, half way up his arm, to get his hands out of the 
sleeves, ... He was altogether, as roistering and swaggering a young gentleman as ever stood four feet six, or something less, in his bluchers. $(O T, 48)$

Artful Dodger is one of the Dickens' outstanding fictional pictures. He is marked with exclusive casual speech, a distinguishing physical sketch and anomalous gestures (a sudden twitch of the head to keep his hat from falling). His description in this chapter is typical of Dickens's adept use of details. For example his snub nose, ugly eyes, wearing a man's coat which is loose for him, are some images of a caricature or in other cases a scarecrow and grotesque picture. Harvey Peter said: "The Artful Dodger draws attention to the social conditions which forced children to become adults before their time" (314).

The next important character is the old Jew Fagin. In chapters eight and nine, the narrator tells some sentences in describing his appearances:

...was a very old shriveled Jew, whose villainous-looking and repulsive face was obscured by a quantity of matted red hair. He was dressed in a greasy flannel gown, with his throat bare; and seemed to be dividing his attention between the frying pan and a clothes-horse... (OT, 51) ...The merry old gentleman, placing a snuff-box in one pocket of his trousers, a note-case in the other, and a watch in his waistcoat pocket, with guard chain round his neck, and sticking a mock diamond pin in his shirt, buttoned his coat tight round him, and putting his spectacles-case and handkerchief in his pockets, tottered up and down the room with a stick, in imitation of the manner in which old gentlemen walk about ... $(O T, 57)$

Here Fagin's clothes and the roles he is playing in front of Oliver are like a buffoon act performing in a circus. The idea of playful grotesque can be applied to this character. The main idea about playful grotesque is to deride a situation or character. Harvey Peter wrote "the ironic concept of Fagin as a merry old gentleman should have been kept exclusively to suggest Oliver's naïve view of him" (143).

In chapter eleven, after arresting Oliver by the police when he is in the parlor, the narrator starts to describe Mr. Fang, the police magistrate, and wants to sentence Oliver Twist without any evidences as follows that is a comic description of a police magistrate: 
Mr. Fang was lean, long-backed, stiff-necked, middlesized man, with no great quantity of hair and what he had growing on the back and sides of his head. His face was stern and much flushed. If he were not really in habit of drinking rather more than was exactly good for him, he might have brought an action against his countenance for libel and have recovered heavy damage... $(O T, 65)$

Dickens' use of adjectives shows a funny picture for him: “...no great quantity of hair... his face was stern and much flushed...” are as a man is describing a funny picture. Again this old man is in the mode of a buffoon and playful grotesque. Harvey Peter notes down about this picture of Mr. Fang as "a brief satirical sketch" (255).

In the opening of chapter thirteen, there is one sign of the animal portrait appears when Fagin is looking at the Charley Bates as "...his turn to be throttled second, drop upon his knees, and raised a loud, well-sustained, and continuous roarsomething between a mad bull and a speaking trumpet" (OT, 77). In this part Dickens tries to have more than one image which are trumpet and a bull. So the mixing of opposites which have no natural connection is another factor of grotesquery.

Mr. Sikes is appeared in this chapter. From the first, He is described as a person observed by a young man a monster of ferocity:

The man growled out ...in a black velveteen coat, a very soiled drab breeches, lace-up half boots and gray cotton stocking, which enclosed a very bulky pair of legs, with large swelling calves- the kind of legs that, in such costume, always look in an unfinished and in complete state without a set of fetters to garnish them... and a dirty belcher handkerchief round his neck...a broad heavy countenance with beard of three days' growth, and two scowling eyes,...(OT, 78)

His physical appearance is very murky and while unfolding his appearance, there are some moments of laughing and scaring that pose the reader in a fuzzy situation. This pattern is closely related with the idea of mixing sentiments in grotesque. Lucas states that clothes imagery in this novel is a kind of dehumanized clothes, which the reader cannot make out the values of human. They all represent the horror of a society which has lost its humanity and is mixed with the ideas of savage and hunts (41). 
Mr. Grimwig talks about two types of young boys in a very nonstandard form for a human, which is mixed with some features of animals:

"I know a friend who has a beef-faced boy- a fine boy, they call him- with round head and red cheeks and glaring eyes, a horrid boy, with a body and limbs that appear to be swelling out of the seams of his blue clothes, with the voice of a pilot and the appetite of a wolf, I know him The wretch!” $(O T, 88)$

The animal imagery as a grotesquery factor is visible. Having limbs out of the coat, beef-faced picture of a boy, and appetite of a wolf are traces of animal imagery and bizarre grotesquery.

After getting Oliver by Nancy, the people around calls him as "young dog” (OT, 96) which in this time Dickens starts to diverse the plot. It means that again Oliver Twist is got stuck in a blue situation which he wants to escape but people of the society never believe this young boy. Otherwise after returning, Nancy calls him a "lamb" and Sikes calls him "Carcass" $(O T, 133)$. Putting animal names on a human have two connotations one negative and one positive in the funny form. But negative is something that one degrades a human to an animal which contains tragic ideas toward adult readers.

In chapter twenty-four, narrator describes the old crone who is the nurse in the time of Oliver's birth, on his mother bed in grotesquery form. As the narrator states:

It was no unfit messenger of death that had disturbed the quiet of the matron's room. Her body was bent by the age, her limbs trembled with palsy, and her face, distorted into mumbling leer, resembled more the grotesque shaping of some wild pencil than work of nature's hand. $(O T, 152)$

In this part the idea of terror is the grotesquery element. Also description of an old woman like a fortuitous drawing by the nature is another point toward grotesque. Here the story got his turning point toward the life of Oliver. In this chapter the secret of his life is appeared on the scene of a theater-like form of narration. Lucas mentions Oliver has to face the helpless and entirely human rage of a world which society has had its share in creating but for which it denies all responsibility (54). It is in this time that Dickens wants to show the real phases of Oliver's life by the help of the old grotesquery woman. Oliver must live as what society considers for him. 
In the following chapter when Sikes leaves the boy in the ditch, Fagin started to show his anger toward his deed by mentioning: “...listen to me, you drab. Listen to me who with six words, can strangle Sikes as surely as if I had his bull's throat between my fingers free, and, dead or alive, fails to restore him to me...(OT, 165). Fagin puts these words just for the money he could receive to return Oliver and in this time he has lost him because of Sikes' job and Nancy, due to her love to Sikes, is puzzled to do anything. Then Fagin continues and tells the reason of his anguish: "when the boy's worth hundred of pounds to me" $(O T, 166)$. Once, Oliver is imaging the picture of fly for himself because of his sores on his body. Here the elements of grotesquery are the hopes of a young fellow to have wings to become free of that harsh place which "the unresolved clash of incompatibles in work and response" (Thomson 27): "Flight! He could scarcely stand; and if he were in full possession of... whither could he fly?” (OT, 181), this sentence or dream is funny for an adult reader that also has the misery sense in depth.

In this part Dickens changes the mood of the story to a comic scene after Oliver could stand up and go to the house, where he wants to steal from last night. By bashing at the door, everybody in the house jumps to become afraid of what was going to happen. But they pretend hearing nothing and continue their dialogues : "I'll call up that poor lad, Brittles, and save him from being murdered in his bed, or his throat, I say, may be cut from his right ear to his left without his ever knowing it” $(O T, 181)$. The playful grotesque which its goal is mocking objects is justifiable on the characters. Dickens put them as thoughtless characters just play-acting of being heedless about what they are hearing. The grotesquery concept of comic and terrifying are appreciable in the characters' dispositions.

In chapter thirty, there is one moment which gets a very smooth sense of childhood for an adult reader that Dickens has described in some sentences. In other case a dream of a child is explained a follows:

The boy stirred and smiled in his sleep, as though these marks of pity and compassion had awakened some pleasant dream of love and affection he had never known; as strain of gentle music, or the rippling of water in a silent place, or odor of a flower, or even the mention of a familiar word... $(O T, 189)$

Oliver is a child having a sense of incorruptibility in his mind and tries to escape from the world of grown-ups. Dickens tries to show the regulations of Victorian England are punitive because if Oliver were not protected by the doctor, he had been treated as an adult criminal. The clash of unsettled incompatibles as the 
innocence of the child and the harshness of the adult society is the grotesquery elements. The child is in the hope of love and fondness that he had never received. He dreams of places which seem bizarre in his real life.

The idea of animals is repeated in the novel again when Sikes tells himself as "a sick rat in his hole” $(O T, 254)$ and also when Fagin is talking with the Nancy and wants her to "revenge on those that treat you (her) like a dog- like a dog! Worse than a dog, for ..." (OT, 295), putting emphasis on the life of the characters as unkempt and unheeded ones is the task of this animal imagery.

Nancy talks about the Monk in the time of appointment with Rose and explains him as follows:

...for his eyes are sunk in his head so much deeper than any other man's, that you might almost tell him by that alone. His face is dark, like his hair and eyes; and, although he can't be more six- or eight and twenty, withered and haggard. His lips are often discolored and disfigured with the marks of teeth; for he has desperate fits, and sometimes even bites his hands and covers them with wounds... (OT, 306)

The model of explaining is like a black monster that has his body hurt like eyes are sunk in his head so much deeper than any other man's, his face is dark, the paleness of his lips, and the misshape of his face because of his teeth. In this grotesquery combination of appearance the idea of caricature also is noticeable.

The time of Sikes' death combines the comic and tragic senses:

...he lost his balance and tumbled over the parapet. The noose was at his neck. It ran up with his weight, tight as a bowstring, and swift as the arrow it speeds. He fell for five-and-thirty feet. There was a sudden jerk, a terrific convulsion of the limbs; and there he hung, with the open knife clenched in his stiffening hand...the old chimney quivered with the shock, but stood it bravely. $(O T, 337)$

Sikes has paid clearly for his own ugly crime. "Betrayal and murder of Nancy in spite of her love destroy Sikes himself, disrupt Fagin's band, and disorder society" (Fielding 38). His dog's death also is followed by his death but some critics mentions that this scene is regarded as a bit too melodramatic. 


\section{B. Environment}

Environments in this novel are gloomy and in gothic grotesquery. In this novel from the starting points, the narrator puts a gloomy atmosphere of Victorian slums and rest of the society in a dark and frightening way, especially when Oliver wants to go there or faces with those places. The first important and most impressive place is the undertaker's shop:

....an unfinished coffin on black trestles, which stood in the middle of the shop, looked so gloomy and deathlike that a cold tremble came over him every time his eyes wandered in the direction of the dismal object- from which he almost expected to see some frightful form slowly rear its head to drive him mad with terror. Against the wall were arranged, in regular array, a long row of elm boards cu into the same shape; looking, in dim light, like high shouldered ghosts with their hands in their breeches-pockets. ...the shop was close and hot, and the atmosphere seemed tainted with the smell of coffin. The recess beneath the counter in which his flock mistress was thrust looked like a grave. (OT, 278)

In this place the ghastly and macabre descriptions (horrifying description) as the smell of coffin and high shouldered ghost as the components of grotesque (Thomson 36) are carefully linked to Oliver's lookout. His fear and horror of situation is determined to arouse pity for him as the narrator tells "nor were these the only dismal feelings which depressed Oliver. He was alone in a strange place; and we all know how chilled and desolate the best of us will sometimes feel in such a situation" $(O T, 28)$.

In chapter eight, when Oliver is going to London, walking picture is recounted as the place in a deserted area causes horror to a young boy. Gothic grotesque is comprehensible:

Early on the seventh morning after he had left his native place, Oliver limped slowly into the little town of Barnet. The windows-shutters were closed; the street was empty, not a soul had awakened to the business of the day. The sun was rising in all its splendid beauty, but the light only served to show the boy his own lonesomeness and desolation, as he sat, with bleeding feet and covered with dust, upon a cold doorstep. (OT, 48) 
The closed windows' shutters and desolation of the streets are the samples of a deserted place. According to Lyn Pykett, Oliver's arrival in and departures from London, and his walk there, develops a particular way of thinking about the city and the sense of being-in-the-city. It is a social cartography, which maps the city as a series of class-differentiated zones, planning its relationships with and to suburbs and country, safe places of the high classes. Writer wants to reveal something of the realities of life in London to the readers who has no conception of them.

Dickens puts his mastery in account in this part that he tries to elucidate the slums of London and especially 'the Saffron Hill the Great' where Dickens himself has had some kinds of familiarity about in his childhood:

The street was very narrow and muddy, and the air was impregnated with filthy odors. There were a good many small shops; but the only stock in trade appeared to be heaps of children, who, even at that time of night, were crawling in and out the doors, or screaming from the inside. The sole places that seemed to be prosper, amid the general blight of the place, were the public-house; and in them the lowest orders of Irish were wrangling with might and main. Covered ways and yards, which here and there diverged from the main street, disclosed little knots of houses, where drunken men and women were positively wallowing in the filth; and from several of the doorways great ill-looking fellows were cautiously emerging, bound, to all appearance, on no very well-disposed or harmless errands. $(O T, 51)$

Crawling drunken men and women, the ill-looking fellows are the elements of grotesquery as gothic-mode descriptions. Harvey Peter mentions that when Dickens wanted to picture Saffron Hill, a choice for thieves in London of his day, he inserted periphrasis in the mockingly exaggerated style only as a second thought. The place in a terrifying description or in other case gothic grotesque is noticeable as the dominant element of description. The picturesque element of the novel provides Dickens with chances he needs for confronting his reader with those areas of the society that they don't like to go. Dickens tries to show them everything they are refusing to see.

Another place that can be mentioned as grotesquery description is the Grosvenor square: 
For anything Oliver knew contrary. The night was dark and foggy. The lights in the shops could scarcely struggle through the heavy mist, which thickened every moment and shrouded the streets and houses in gloom, rendering the strange place still stranger in Oliver's eyes, and making his uncertainty the more dismal and depressing. $(O T, 98)$

In this scene the area is defined as the way that leads to the events that are going to ensue for Oliver. As the Saffron Hill the Great, graphic features are the same to have grotesquery pictures (the description which arouses fear in the reader). The foggy and dark night, the creepy lights of shops through hefty mist and dimness of streets in Oliver's eyes are elements of grotesque.

The place that Oliver has been jailed in Fagin's house is described as a very dirty place.

It was a very dirty place. The rooms upstairs had great wooden chimney-pieces and large doors...they were black with neglect dust...spiders had built their webs in the angels of the walls and ceiling, and sometimes, when Oliver walked softly into a room, the mice would scamper across the floor, and run back terrified to their holes...(OT, 114-15)

This room recalls the house of Miss Havisham in Great Expectations which she confined herself in, and her house was changed to the old castle of loneliness. Spiders on all places of the house, the blackness and darkness of the house are some features of gothic grotesquery. Terry Eagleton states that the den of the thieves of Fagin is a distorted version of family, and Fagin is a father figure to Oliver.

In the search of Sikes, Fagin goes to a place which has been called Three Cripples. There has been a party and the saloon is described in a darkened mode that is the element of terrifying grotesque:

The ceiling was blackened, to prevent its color from being injured by the flaring of the lamps, and the place was so full of dense tobacco smoke, that at first it was scarcely possible to discern anything more. By degree, however, as some of it cleared away through the open door, an assemblage of heads, as confused as the noises that greeted 
the ear, might be made out, and as the eye grew more accustomed to the scene, the spectator .... p professional gentleman, with a bluish nose, and his face tied up for the benefit of the toothache, presides at a jingling piano in a remote corner... $(O T, 163)$

The color, its black ceiling and tobacco smell dense are the elements of terrifying grotesque.

The house of the Monks is described as a castle in the water that is going to be demolished by nature, and the element of Gothic grotesque:

Stood a large building, formerly used as a manufactory of some kind...but it had long since gone to ruin. The rat, the worn, and the action of the damp had weakened and rotted the piles on which it stood, and a considerable portion of the building had already sunk down into the water beneath; while the reminder, tottering and bending over the dark stream, seemed to wait a favorable opportunity of following its old companion and involving itself in the same fate. $(O T, 242)$

Lucas mentions that Monks symbolizes the plague impairs the marriage hearse. He is the one who has all evil cravings and vices. He helps the reader to direct his attention to one of the novels' most notable features which is obsession with death (44-5). His castle also is in the same way of feeling as an old grave yard.

The Thames River has been described beautifully as the effects of industries on it:

Near to that part of the Thames on which the church at Rotherhithe abuts, where the buildings on the banks are dirtiest and the vessels on the river blackest with the dust of colliers and the smoke of close-built low-roofed houses, there exists, at the present day, the filthiest, the strangest, the most extraordinary of the many localities that are hidden in London, wholly unknown, even by name, to the great mass of its inhabitants... (OT, 329)

The description is full of nonsensicality of river bank and surrounding areas. The dirty bank of river, being blackest, and smoke are some elements of ridiculing the river. Here the playful grotesque is the means of lampooning the society. 
There is a place called Jacob's Island that Sikes has escaped to. This place has been abandoned long ago and houses and especially warehouses are started to be eradicated by the nature:

In Jacob's Island the ware houses are roofless and empty, the walls are crumbling down, the windows are windows no more, the doors are falling into streets, the chimneys are blackened, but they yield no smoke. Thirty or forty years ago, before losses and chancery suits came upon, it was a thriving place, but now it is a desolated island indeed. The houses has no owners, they are broken open, and entered... (OT, 330)

Roofless and empty houses, destruction of windows and falling doors are the elements of a destructed island. H.M. Daleski states Jacob's island is the place where two worlds of the novel meet, where home is only distinct from the streets. But Jacob's Island is not only the meeting-place of homes and streets, but also it is the joining point of crime and poverty, for those who refuge in it either has powerful reasons for secret dwelling or condensed to a poor condition. What the narrative emphasizes is that the workhouse leads to Jacob's Island, that for Oliver there is no other home and that they take up residence there, closely stuck with the criminal.

\section{Situations}

In this novel the readers are faced with different situations that are comprised as comic, witty, tragic that can be categorized as grotesque in the terms of Irony, comic, and disharmony. The Dickens' uses of speech are completely satirical. One idea that is very common in this novel is the idea of 'cannibalism'. In the opening chapters Oliver in the parish work house faces with starvation. “...he was afraid he might be some night happening to eat the boy who slept next to him, who happened to be a weakly youth of tender age”. $(O T, 12)$ Dickens according to some critics is satirizing not only the Poor Law of 1834 but also form of charity which seeks to eliminate poverty by starving the poor.

In chapter four there is a moment that Mr. Bumble takes him to the undertaker's shop, Oliver faces with harsh moments, and the narrator says some sentences that are in disharmonious style:

I wish some well-fed philosopher, whose meat and drink turn to gall within, whose blood is ice, whose heart is iron, could have seen Oliver Twist clutching at the dainty 
viands that the dog had neglected. I wish he could have witnessed the horrible avidity with which Oliver tore the bits asunder with all the ferocity of famine. $(O T, 27)$

Here death used as a symbolic device, helps to unify and intensify the allegorical struggle between good and evil that is at the novel's core.

Oliver in one point is talking about his parents that were dead, and he put some images in his mind about them that somehow those images are in his dream as he himself mentions. "Because Heaven is a long way off, and they are too happy there to come down to bedside of a poor boy" $(O T, 70)$. In this part the ideas of childhood and adulthood are mixing for an adult reader.

Oliver also is afraid when he is alone on his bed. The narrator puts some ideas in the text about death and in the boy's mind that are terrifying for a young boy:

The darkness and deep stillness of the room were very solemn, and as they brought into boy's mind the thought that death had been hovering there for many days and nights, and might yet fill it with the gloom and dread of his awful presence, he turned his face upon the pillow and fervently prayed to Heaven.” $(O T, 71)$

The macabre description is the grotesquery element here. Darkness and deep silence of the room, thought of death, and murkiness of his attendance are the descriptions that are eccentric and odd for a young boy.

Assisting Dodger in his toilet once makes Oliver happy that he becomes useful. It is the mixture of comic and grief for readers:

"He condescendingly commanded Oliver to assist him in his toilet. Oliver was but too glad to make himself useful, too happy to have some face, however bad, to look upon, and too serious to conciliate those about him...” $(O T, 114)$

The description of the night and the streets are one of the powerful aspects of Dickens' visualization in this novel. The grotesquery element is the eccentric description of the night and surrounding areas. They are ghastly and horrific:

The night was bitter cold. The snow lay on the ground, frozen into a hard thick crust; so that only the heaps that had drifted into by-ways and corners were affected by the sharp wind that howled abroad: which, as if expending 
increased fury on such prey as it found, caught it savagely up in clouds, and, whirling it into a thousand misty eddies, scattered it in air. Bleak, dark, and piercing cold, it was a night for the well-housed and fed to draw round the bright fire and thank god they were at home; and for the homeless starving wretch to lay him down and die. Many hunger-worn outcasts close their eyes in our bare streets, at such times, who, let their crimes have been what they may, can hardly open them in a more bitter world. $(O T, 144)$

In this passage the various differences of condition that distinguish one man from another are narrowed to one basic distinction: between 'the homeless' and 'the wellhoused', between 'poor naked wretches' and 'accommodated man'. The distinction is as a result between a man's having a home, which provides him shelter, food, warmth and light; and being condemned to be out in the vacant streets, which means being exposed not only to the cold and the dark but also to hunger. As $\mathrm{H}$. M. Daleski states "To be out in the streets is to move through the darkness of a hell on earth, for those who die in the streets. To have a home is a mark of grace and the well-housed may duly thank God they are at home". (50)

At one point, there is the grotesque comedy of Bumble wondering whether he should marry Mrs. Corney:

Mr. Bumble's conduct on being left to himself was rather inexplicable. He opened the closet, counted the tea-spoons, weighed the sugar tongs, closely inspected a silver milkpot to ascertain that it was of the genuine metal, and having satisfied his curiosity on these points, put on his cocked that corner-wise, and danced with much gravity four distinct times round the table. Having gone through this very extraordinary performance, he took off the cocked hat again and, spreading himself before the fire with his back towards it, seemed to be mentally engaged in taking an exact inventory of the furniture. (OT, 151)

Here Mr. Bumble expresses his excitement at the prospect of acquiring Mrs. Corney's property with a ridiculously solemn way.

Harvey Peter declares that Dickens makes it clear that Bumble is the formation of a materialistic society. The marriage of Mrs. Corney and the beadle represents the final degradation of such society. "The institution which should express the 
consummation and stability of human love is reduced to a squalid financial maneuver”. (321)

There is another part that the narrator claims something in very comic way but principally tragic, this combination is a feature of grotesque, as the shopkeepers put their things to be robbed by the thief, "here the clothes man, the shoe-vamper, and the rag-merchant display their goods, as sign-board to the petty thief” $(O T, 161)$.

When Rose starts to cry in the last part of chapter thirty six, she has got two types of feeling that the writer puts them together to put the reader in a wandering mode, between sorrow and joy: "tears are signs of the gladness as well as of grief; but those which coursed down Rose's face, as she sat pensively at the window, still gazing in the same direction, seemed to tell more of sorrow than of joy" $(O T, 233)$. Aberration or mixing of moods is another part of grotesquery. Phillip Thomson mentions the experience of amusement and disgust, laughter and horror, mirth and revulsion, simultaneously, can be categorized under the name of grotesque. (24)

There is another moment which puts the reader in a form of smiling and shocking. When they put Dodger in the court and they want to put some sentences on him, and he just tries to delay the conversation by using witty sentences:

...silence there!' cried the jailer.

What is this?' inquired one of the magistrates.

A pick pocketing case, you worship.

Has the boy ever been here before?

He ought to have been, a many times,' replied the jailer. 'He has been pretty well everywhere else. I know him very well, your worship.' Oh! You know me, do you?' cried the Artful, making a note of the statement. 'Wery good, that's a case of deformation of character anyway.' ... Now then, where are the witnesses?' said the clerk. Ah! That's right, added the Dodger. 'Where are they? I should like to see 'em.' This wish was immediately gratified, for a policeman stepped forward who had seen the prisoner attempt to pocket of an unknown gentleman in a crowd, and indeed take a handkerchief there form which, being a very old one, he deliberately put it back again, after trying it on his own countenance... (OT, 290)

It is necessary to be declared that there is a comparison between the courtroom scenes with the one in chapter eleven. Again Dickens directs his satire at the legal system that denies its victims due to method of law. Dickens lets Dodger 
commands the scene in his own rough manner and makes some sharp comments about the legal system. According to H. M. Daleski the view of Artful Dodger's defiance of the court which puts him as representatives of struggle of poor against the state is to blur the basic change between poor and criminal. (57)

Another aspect of the novel can be set as expression of laughter and sorrow which Dickens has used in his novel by the help of comic scenes and characters. $\mathrm{R}$. Kincaid mentions Dickens has used laughter here to subvert our conventional reactions and to emphasize more dramatically the isolation of his young hero, indeed, the essential isolation of all men. In denying the possibility of a comic society and yet provoking laughter, the novel repetitively frustrates the reader, for his laughter continues to search for a social basis, even when there is no longer any supports for it in the novel. Kincaid continues that "like Dodger, all Fagin's boys are adept at parody and speak a language which constantly makes fun of petrified, respectable world" (73).

When Nancy is going to the appointment, the narrator puts some sentences in opposite forms of each other, another sign of disharmony and one of the grotesquery elements.

Midnight had come upon the crowded city. The palace, the night-cellar, the jail, the madhouse, the chambers of birth and death, of health and sickness, the rigid face of the corpse and the calm sleep of the child, - midnight was upon them all. (OT, 301)

Death and birth, health and sickness, corpse and child are some examples of the grotesque as a device which is well-defined as the clash of opposites.

As Dodger in the court is doing something inappropriate to the situation, Fagin also starts to think about something funny and irrelevant in the court:

In the same way when he turned his eyes toward the judge, his mind began to busy itself with the fashion of his dress, and what it cost, and how he put it on. There was an old fat gentleman on the bench, too, who had gone out, some half an hour before, and now come back. He wondered within himself whether this man had been get his dinner, what he had, and where he had it, and pursued this trains of careless thought until some new object caught his eyes and roused another... (OT, 350) 


\section{Conclusion}

Dickens early interest in crime and criminals lasts all his life. Perhaps no other Victorian novelist has had so great understanding of or sympathy for those condemned to die. Fagin, like Sikes, becomes at the hour of death an object not of contempt but of pity. Dickens expertly makes Fagin's grief more mental than physical. He is a man of wit and imagination; therefore he has to pass his last hours imaging his death. Almost everyone who has written about Oliver Twist has apprehended that the most interesting parts of it are those about the criminal underworld. K. J. Fielding writes Dickens' purpose was undoubtedly partly to show criminals were made not born, and they took to crime because they knew nothing better. Yet Oliver, himself, brought up on a baby-farm and in a workhouse, is naturally good, he takes no detriment from his associates, and he succeeds in spite of the absence of chance and luck (35).

This novel has a dual moral purpose to show the sinful working of the Poor Law Act and to give a faithful picture of thieves' lives in London. Dickens, in preface to Oliver which was written in 1841, has mentioned its second drive, and has walled himself against critics who had demurred to his dealing with the lives of pickpockets and burglars. David Daiches in his essay "the Victorian novel: Charles Dickens World" in the book a Critical History of English Literature mentioned that Oliver Twist moving between workhouse on the one hand, and kind protection on the other, with a third alarming option of violent acceptance into one of the criminal gangs of London, exists not so much to be saved as to show different kinds of setting into which innocence may fall. The book is full of nightmare symbols of loss, isolation, and imprisonment (4: 26). Oliver Twist is more an allegorical fairy tale than a novel. It is a fable drawn in very large degree and peopled with usually symbolic figures. The good characters are drawn lightly; the villains (Sikes, Fagin, Monks) are drawn in the blackest possible manner. Fagin is comical and somewhat sympathetic at times, compared to Sikes, but he is a caricature. Dickens wants to show clumsiness and awkwardness of the life of thieves and boys who are living among the people and are invisible for the citizens. He starts to show those absurdities of their lives by grotesquery images and concepts. By comic characters and tragicomic situations, he makes them discernible. The environments that are utterly unalike from what high-class people believe are made clear for them. So he as a writer, satirist and cartographer tries to make, paint and plan hidden lives of London and its people. 


\section{REFERENCES AND NOTES:}

Ackroyd, Peter. Dickens. New York: Harper, 1990.

Chesterton, G. K. Criticism and Appreciation of the works of Charles Dickens. New York: Dutton, 1911.

Clayborough, Arthur. The Grotesque in English Literature. Oxford: Clarendon Press, 1965.

Collins, Philip A. W. Dickens and Crime. New York: St. Martin’s Press, 1962.

Connor, Steven. Charles Dickens. Oxford: Blackwell, 1985.

Cuddon, J.A. A Dictionary of Literary Terms. New York: Penguin Press, 1984.

Daiches, David. “Charles Dickens’ World”. A Critical History of English Literature. New York: Roland, 1970.

Daleski, H. M. Dickens and the Art of Analogy. London: Faber and Faber Limited, 1970.

Dickens, Charles.Oliver Twist. Hertfordshire: Wordsworth, 1992.

Dyson, A. E. The Inimitable Dickens. London: Macmillan Press, 1970.

Dyson, A. E. Dickens: Modern Judgment. London: Macmillan Press, 1968.

Eagleton, Terry. The English Novel. Oxford: Blackwell, 2005.

Fielding, K. J. Charles Dickens: a critical introduction. London: Longmans, 1965.

---. Charles Dickens: The Speeches. London: Billing and Sons Limited, 1988.

Forster, John. The Life of Charles Dickens. 2 Vols. London: Dent, 1966.

Gilmour, Robin. The Victorian Period: The Intellectual and Cultural Context of English Literature (1830-1890). New York: Longman, 1996.

Gissing, George R. Critical Studies of the Works of Charles Dickens. New York: Greenberg, 1924.

Gomme, A.E. Dickens: Literature in Perspective Ed. Kenneth Grose. London: Evans Brothers Limited, 1971.

Gorman, Francis O. The Victorian Novel: A Concise Companion. Oxford: Blackwell, 2005. ---. The Victorian Novel. Oxford: Blackwell, 2002.

House, Humphry. The Dickens World. London: Oxford University Press, 1961.

Jacobson, Arnie. Cliff Notes on Great Expectations. Nebraska : Cliff Notes, 1992.

Jordan, John O. Charles Dickens: the Cambridge Companion. New York: Cambridge University Press, 2001.

Kayser, Wolfgang. The Grotesque in Art and Literature. Translated by Ulrich Weisstein. Bloomington: Indiana University Press, 1957.

Kincaid, James R. Dickens and the Rhetoric of Laughter. Oxford: Clarendon Press, 1971.

Lucas, John. The Melancholy Man: A study of Dickens' novels. Totowa: Barnes and Noble, 1980.

Morgan, Lee. A Handbook of Critical Approaches to Literature. New York: Harper and Row Publishers.

Pritchett, V. S. "the comic world of Dickens”, The Victorian Novel: Modern Essay in Criticism. Ed. Ian Watt. New York: Oxford University Press, 1971.

Price, Martin. Dickens: A collection of critical essays. Englewood Cliffs: Prentice-Hall, 1967.

Pykett, Lee. Charles Dickens: Critical Issues. New York: Palgrave, 2002.

Sell, Roger D. Great Expectations: New Casebooks. London: Macmillan, 1994.

Sucksmith, Harvey Peters. The Narrative Art of Charles Dickens. Oxford: Clarendon, 1970.

Steig, Michael. "Defining The Grotesque: An Attempt at Synthesis”, in Journal of Aesthetics and Art Criticism, summer 1970: 259-60 .

Thomson, Phillip. The Grotesque. London: Methuen Ltd, 1972.

Wall, Stephen. Charles Dickens: A Critical Anthology. England: Penguin Books Ltd., 1970. 


\title{
Summary
}

\section{Oliver Twist and Inklings of 'Grotesque'}

\author{
Ehsan Hafezi Kermani \\ Sabz Institute of Higher Education, Iran \\ Roshanak Fazli \\ Sabz Institute of Higher Education, Iran
}

Oliver Twist is a novel in which the society of pilfers and felons were reconnoitered uninvited by a young boy whose name is Oliver in the Victorian period. He as an orphan faces with dissimilar circumstances that are concealed to the eyes of the conventional people. Dickens, as the narrator of the story, has logged those absurdities and clumsiness in his novel.

Dickens uses the idea of grotesque to display the conditions and the scenes to alert people in forms of comic and tragic. Dearth, poverty, lives of thieves, and whatever ensued in his time are dexterously exhibited in this novel by using grotesquery which its function is 'mixing emotions, tragicomic, abnormality'. He uses melodramatic techniques with grotesque and humorous characterization. He exchanges tragic and comic scenes to balance one against another.

Grotesque in Oliver Twist mainly can be debated in three formulas that are comprised as caricature-like characters, Gothic-like environment, and a means of satirizing situations.

Key Words: Charles Dickens, Grotesque, Caricature, Gothic, Satire, Bizarre, Macabre 